\title{
About Eastern Udmurt Religious Practice Today
}

\author{
Eva Toulouze* \\ Principal investigator and team coordinator, Professor of Finno-Ugric studies in INALCO, France
}

Submission: February 21, 2018; Published: April 11, 2018

*Corresponding author: Eva Toulouze, Principal investigator and team coordinator, Professor of Finno-Ugric studies in INALCO, Paris, France, Email: evatoulouze@gmail.com

\section{Opinion}

An international five-year project has been launched with the support of the French State-supported institution IUF (Institute universitaire de France) about the Eastern Udmurt's religious practice today. Why is it a challenging research in today's world? What are our research goals? How do we intend to achieve them?

The Easter Udmurtare an ethnic group living in Bashkortostan, a Turkic Republic in Central Russia. They migrated from their original area, encompassed within what is nowadays the Republic of Udmurtia, since the $16^{\text {th }}$ and mostly the $17^{\text {th }}$ century, when they fled forceful Evangelisation and found propitious live conditions in a tolerant Muslim environment, where they settled and pursued their life as formerly. They were "protected" against the Orthodox missionaries' interference by surrounding Islam. Therefore they were able to maintain their original Udmurt agrarian religious ceremonies and their worldview. Of course, in time, there were natural transformations and the Soviet regime's anti-religious policy was the same all over the Union and touched the Muslim republics as well as other territories. Still in some places, religious practice has continued without any interruption; in others, collective ceremonies have been discontinued only for a few years. At the beginning of the $21^{\text {st }}$ century, everywhere religious practice has been revitalised. There are in every village sacrificial priests, often more than one, and the elder choose among the young participants their successors. Thus, it is a living example of agrarian religion, which is meaningful in the people's lives, and which is fundamentally tolerant: as a young sacrificial priest summed up for us: There is one God; only the forms of worship are different. Therefore, they have no problem in coexisting with Islam or with Christianity, wherever the latter accept them.

We are a group of researchers in a team I coordinate, coming from different disciplines, different countries and different mother tongues. The main basis of team is Estonia, where half of it lives: Nikolai Anisimov is an Udmurt folklorist, who just defended his PhD theses in Tartu University (Estonia) who comes from Southern Udmurtia; Liivo Niglas is an Estonian visual anthropologist, who has been recording Udmurt ceremonies for five years; Laur Vallikivi is a Cambridge $\mathrm{PhD}$, specialist in Anthropology of religions, whom experience with the peoples of the North confer interesting comparative perspectives; Irina Pchelovodova is an Udmurt ethnomusicologist working in the Udmurt research institution of the Academy of Sciences; Ranus Sadikov is an Udmurt ethnographer working in the Bashkir research institution of the Academy of Sciences, who has defended his thesis about Udmurt religion; so is Tatyana Minniyakhmetova, who is working in Innsbruck university and has defended her PhD about Udmurt religion in Tartu both she and Ranus come from the communities we study. The last member of the team is the ethnology professor in Pécs (Hungary), Zoltán Nagy, who is also an anthropologist. Thus I want to emphasise the importance, in this team, to join forces both from within and from without: Ranus and Tatyana are members of the communities under examination, while being themselves scholars; Nikolai and Irina are members of a wider community of Udmurt, although they belong to another ethnic group, but they are able to make fieldwork in Udmurt - so they have both a point of view from within the Udmurt culture and from without the concrete ethnic group; and among the other scholars, I have been studying the Udmurt culture for 25 years while my colleagues have all a huge experience with Khanty and Nenets communities. Thus we may confront different points of view and ensure a rich reflexion on our fieldwork observations.

We have identified different focuses joining documentation, which is scarce, and investigation. Some themes we want to reflect upon are general: we are interested in reflecting about animism, ethnic religions, Neopaganism and New Age at the beginning of the $21^{\text {st }}$ century in order to put our fieldwork conclusions in perspective into a more theoretical approach; in the same order of reflections we want to understand how to relate to Udmurt religion: is it indeed a form of animism? Clearly the answer to these questions will have to be found in observation to be undertaken in these five years.

We shall concentrate on different forms of religious practice, and the first, the one we have been working on during the last five years, is the collective village ceremony, as well as 
ceremonies encompassing several villages. Now, on the bases of this experience and the acquaintances we have made in the last years, we may investigate more intimate rituals, held at family level, as the commemorative ceremonies for the dead, or the seasonal family forms of worship. We are for example attending in a few weeks the ceremonies for the equivalent of Eastern, the Great Day (Badzhynnal). In the same way, we may now be invited to other kinds of ceremonies, as the consecration of a new house, a birth or a departure for the army. In connection with these ceremonies, we are going to study different aspects: the sacred places, the role of the sacrificial priest and of the village community, as well as the texts of the prayers. We'll dedicate special attention to the cemeteries and the cult of the dead, as well as to marriages, which are performed, in these regions, through kidnapping of the bride.

We have also decided to pay attention to a delicate theme, witchcraft in the village community. It is a feature still very much present in Udmurt worldview and we shall try, if we are able to understand it, to pinpoint the place of supernatural talents within the village and the relational network that their recognition implies.

Finally we shall investigate two themes that are more external to religious life but that are very thoroughly connected with it: the connections between religious practice and Udmurt identity, and the other is ritual songs: the Udmurt have a very rich song culture, but the Easter Udmurt's has not been thoroughly investigated yet. Therefore, as our project is dedicated to sacred practice, we shall focus on ritual songs, but we consider our research on this point as a first stage to be enlarged in a second volume of songs, the profane ones. We shall attempt to collect both.

The outputs of our work are already noticeable. We have been publishing articles in different journals and in different languages: we agree that we have to publish each in his or her mother tongue, in English and in Russian. The planned outputs have different forms:

a. Paper or/and electronic articles on our fieldwork, without neglecting publishing ethnographies on which we as well as other researchers - may rely

b. A collection of prayers in Udmurt, English and Russian, with comments. We are collecting all the prayers from this area published yet and we have already collected many prayers while filming the ceremonies. We wish to accompany the book with audio or audio-visual materials.

c. A collection of ritual songs, with audio or audio-visual recordings.

d. A collection of collective articles about the abovementioned themes.

e. Moreover, we have been filming different kinds of ceremonies and we are going to release different films of edited material, which shall allow spectators to share the emotions of the participants. The first release of 4 films will take place in Autumn 2018.

f. Some homepages are under construction. One is dedicated to sacred places and will be not be available for the public, for there is still no general agreement on the danger to publicise this kind of places: local scholars are afraid of encouraging plundering. Another is dedicated to old scanned paper photos: albums are being destroyed everywhere by younger generations no longer accustomed to paper photos and ignoring their cultural value. We have started salvaging these photos, which, by the end of the project, will be publicly available. The collected materials will be deposited at the Estonian Folklore Archives.

\section{Your next submission with Juniper Publishers will reach you the below assets}

- Quality Editorial service

- Swift Peer Review

- Reprints availability

- E-prints Service

- Manuscript Podcast for convenient understanding

- Global attainment for your research

- Manuscript accessibility in different formats

( Pdf, E-pub, Full Text, Audio)

- Unceasing customer service

Track the below URL for one-step submission https://juniperpublishers.com/online-submission.php 